\title{
MENEKAN LAJU PENYEBARAN KOLERA DI ASIA DENGAN 3SW (STERILIZATION, SEWAGE, SOURCES, AND WATER PURIFICATION)
}

\author{
Putu Bagus Anggaraditya \\ Fakultas Kedokteran Universitas Udayana \\ (bagusanggraditya@gmail.com)
}

\section{ABSTRAK}

Penyakit taun atau kolera (juga disebut Asiatic cholera) adalah penyakit menular di saluran pencernaan yang disebabkan oleh bakterium Vibrio cholerae. Kolera ditemukan pada tahun 1883 karena infeksi Vibrio cholerae, bakteri berbentuk koma. Penemuan ini ditemukan oleh bakteriologi Robert Koch (Jerman, 18431910).Penyebab kolera, adalah bakteri Vibrio cholerae, yang merupakan bakteri gram negatif, berbentuk basil (batang) dan bersifat motil (dapat bergerak), memiliki struktur antogenik dari antigen flagelar $\mathrm{H}$ dan antigen somatik $\mathrm{O}$, gamma-proteobacteria, mesofilik dan kemoorganotrof, berhabitat alami di lingkungan akuatik dan umumnya berasosiasi dengan eukariot.

Pada orang yang feacesnya ditemukan bakteri kolera mungkin selama 1-2 minggu belum merasakan keluhan berarti, Tetapi saat terjadinya serangan infeksi maka tiba-tiba terjadi diare dan muntah dengan kondisi cukup serius sebagai serangan akut yang menyebabkan samarnya jenis diare yg dialamiCara pencegahan dan memutuskan tali penularan penyakit kolera adalah dengan prinsip sanitasi lingkungan, terutama kebersihan air dan pembuangan kotoran (feaces) pada tempatnya yang memenuhi standar lingkungan. Lainnya ialah meminum air yang sudah dimasak terlebih dahulu, cuci tangan dengan bersih sebelum makan memakai sabun/antiseptik, cuci sayuran dangan air bersih terutama sayuran yang dimakan mentah (lalapan), hindari memakan ikan dan kerang yang dimasak setengah matang.

Kolera memang sudah menjadi momok yang menakutkan di dunia, dan belajar dari negara-negara di Asia yang sudah pernah mengalami wabah kolera, dapat diambil kesimpulan bahwa pengobatan dengan vaksin tidak memiliki pengaruh yang signifikan.Selain karena tidak menjangkau seluruh warga miskin di sebuah negara, harga vaksin kolera juga dirasa cukup memberatkan anggaran negara-negara yang sedang berkembang di Asia.Cara yang dirasa paling tepat dalam menekan laju penyebara kolera adalah 3SW (Sterilization, Sewage, Sources, and Water purification), hal ini mengingatkan kita untuk menjaga keseimbangan Agent, Host, dan Environment.Gangguan pada environment (lingkungan), alam di sekitar kita, akhirnya menyebabkan ketidakseimbangan di sebuah daerah dan akhirnya membawa bencana di wilayah tersebut.

Kata kunci: Kolera, Sterilisasi, Saluran, Sumber, Pengolahan Air, Modifikasi gaya hidup.

\section{PENDAHULUAN}

Penyakit taun atau kolera (juga disebut Asiatic cholera) adalah penyakit menular di saluran pencernaan yang disebabkan oleh bakterium Vibrio cholerae.

Bakteri ini biasanya masuk ke dalam tubuh melalui air minum yang terkontaminasi oleh sanitasi yang tidak benar atau dengan memakan ikan yang tidak dimasak benar, terutama kerang.

Gejalanya termasuk diare, perut keram, mual, muntah, dan dehidrasi. Kematian biasanya disebabkan oleh dehidrasi. Kalau dibiarkan tak terawat, maka penderita berisiko kematian tinggi. ${ }^{1}$

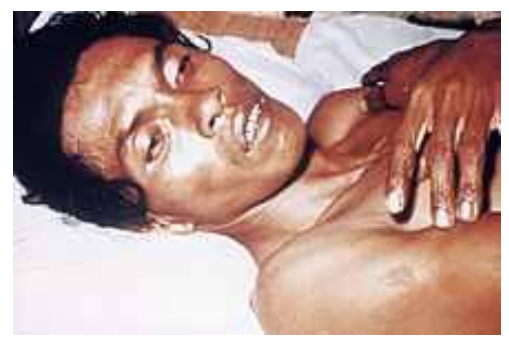

Gambar 1. Penderita Dehidrasi Berat Akibat Kolera. ${ }^{1}$ 
Kolera ditemukan pada tahun 1883 karena infeksi Vibrio cholerae, bakteri berbentuk koma. Penemuan ini ditemukan oleh bakteriologi Robert Koch (Jerman, 18431910).

Sebagai ketua komisi, Koch pergi ke Mesir di mana epidemi sedang berlangsung dan di sana ia menemukan beberapa jenis bakteri di usus yang menyebabkan orang mati karena penyakit kolera tetapi ia tidak dapat mengisolasi organisme atau hewan yang terinfeksi. ${ }^{2}$ Kemudian pada tahun 1883 Koch pergi ke India, di mana ia menulis bahwa ia berhasil mengisolasi bakteri basil berbentuk seperti koma. la menemukan bahwa bakteri tumbuh di pakaian kotor lembab dan di dalam kotoran pasien dengan penyakit tersebut. ${ }^{2}$

\section{Penyebaran Penularan Penyakit Kolera}

Penyebab kolera, adalah bakteri Vibrio cholerae, yang merupakan bakteri gram negatif, berbentuk basil (batang) dan bersifat motil (dapat bergerak), memiliki struktur antogenik dari antigen flagelar $\mathrm{H}$ dan antigen somatik O, gamma-proteobacteria, mesofilik dan kemoorganotrof, berhabitat alami di lingkungan akuatik dan umumnya berasosiasi dengan eukariot. ${ }^{3}$ Spesies Vibrio kerap dikaitkan dengan sifat patogenisitasnya pada manusia, terutama $\mathrm{V}$. cholerae penyebab penyakit kolera di negara berkembang yang memiliki keterbatasan akan air bersih dan memiliki sanitasi yang buruk. ${ }^{4}$

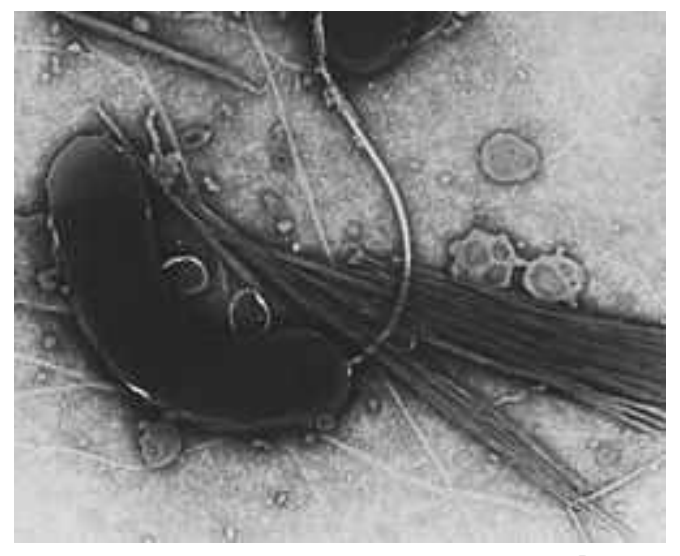

Gambar 2. Bakteri Vibrio cholerae. ${ }^{5}$

Kolera dapat menyebar sebagai penyakit yang endemik, epidemik, atau pandemik. Meskipun sudah banyak penelitian bersekala besar dilakukan, namun kondisi penyakit ini tetap menjadi suatu tantangan bagi dunia kedokteran modern. Bakteri Vibrio cholerae berkembang biak dan menyebar melalui feaces (kotoran) manusia, bila kotoran yang mengandung bakteri ini mengkontaminasi air sungai dan sebagainya maka orang lain yang terjadi kontak dengan air tersebut beresiko terkena penyakit kolera itu juga.

Misalnya cuci tangan yang tidak bersih lalu makan, mencuci sayuran atau makanan dengan air yang mengandung bakteri kolera, makan ikan yang hidup di air terkontaminasi bakteri kolera, Bahkan air tersebut (seperti disungai) dijadikan air minum oleh orang lain yang bermukim disekitarnya.

\section{Gejala dan Tanda Penyakit Kolera}

Pada orang yang feacesnya ditemukan bakteri kolera mungkin selama 1-2 minggu belum merasakan keluhan berarti, Tetapi saat terjadinya serangan infeksi maka tiba-tiba terjadi diare dan muntah dengan kondisi cukup serius sebagai serangan akut yang menyebabkan samarnya jenis diare yg dialami. ${ }^{5}$

Akan tetapi pada penderita penyakit kolera ada beberapa hal tanda dan gejala yang ditampakkan, antara lain ialah :

1. Diare yang encer dan berlimpah tanpa didahului oleh rasa mulas atau tenesmus.

2. Feces atau kotoran (tinja) yang semula berwarna dan berbau berubah menjadi cairan putih keruh (seperti air cucian beras) tanpa bau busuk ataupun amis, tetapi seperti manis yang menusuk.

3. Feces (cairan) yang menyerupai air cucian beras ini bila diendapkan akan mengeluarkan gumpalan-gumpalan putih.

4. Diare terjadi berkali-kali dan dalam jumlah yang cukup banyak.

5. Terjadinya muntah setelah didahului dengan diare yang terjadi, penderita tidaklah merasakan mual sebelumnya.

6. Kejang otot perut bisa juga dirasakan dengan disertai nyeri yang hebat. 
7. Banyaknya cairan yang keluar akan menyebabkan terjadinya dehidrasi dengan tanda-tandanya seperti ; detak jantung cepat, mulut kering, lemah fisik, mata cekung, hypotensi dan lain-lain yang bila tidak segera mendapatkan penangan pengganti cairan tubuh yang hilang dapat mengakibatkan kematian.

\section{Penyebaran Wabah Kolera di India, Pakistan, Bengal, dan Bangladesh}

Kutipan jurnal kedokteran Bangladesh tersebut, berisi perjuangan negara bangladesh dalam usaha menekan laju penyebaran kolera di negaranya.

\section{Reemergence of Epidemic Vibrio cholerae 0139, Bangladesh}

Shah M. Faruque, ${ }^{\star}$ Nityananda Chowdhury, ${ }^{\star}$ M. Kamruzzaman, ${ }^{\star}{ }^{*}$. Shafi Ahmad, ${ }^{\star}$ A.S.G. Faruque, M. Abdus Salam, ${ }^{\star}$ T. Ramamurthy, + G. Balakrish Nair, ${ }^{\star}$ Andrej Weintraub, $\ddagger$ and David A. Sack ${ }^{*}$

During March and April 2002, a resurgence of Vibrio O139 were admitted to the Dhaka Hospital of the cholerae 0139 occurred in Dhaka and adjoining areas of International Centre for Diarrhoeal Disease Research. Bangladesh with an estimated 30,000 cases of cholera. Bangladesh (ICDDR.B). A preliminary estimate showed Patients infected with 0139 strains were much older than that $>30,000$ cases of cholera occurred in Dhaka and the hose infected with 01 strains $(\mathrm{p}<0.001)$. The reemerged adjoining areas during this outbreak (A.S.G. Farupue 0139 strains belong to a single ribotype corresponding to adjul one of two ribotypes that caused the initial O139 outbreak 0139 in 1992 , we have mitored cholen in 1993. Unilike the strains of 1993 , the recent strains are susceptible to timethoprim, sulphamethoxazole, and strep- cor

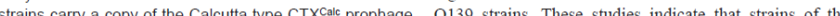
in addition to the CTXET prophage carried by the previous 0139 stans. These studs ind ate hat stains of the strains. Thus the 0139 strains continue to evolve, and the 0139 serogroup are undergoing rapid genetic changes, adult population continues to be more susceptible to 0139 resulting in the origination of new clones, at least seven cholera which suggests a lack of adequate immunity different ribotypes of $O 139$ vibrios have been documented against this serogroup. These findings emphasize the need $(6-8)$. Furthermore, Ol39 vibrios may have originate for continuous monitoring of the new epidemic strains. from more than one progenitor strain (8). The transient dis-

Gambar 3. Kutipan Jurnal Kedokteran Bangladesh. ${ }^{6}$

Berawal dari negara India yang berhasil menekan jenis strain ganas kolera di negaranya, yang akhirnya menyebabkan penyakit tersebut berpindah tempat ke Bangladesh dan dengan cepat menyebar dan membunuh banyak warga Bangladesh. ${ }^{6}$

\section{Penanganan dan Pengobatan Penyakit Kolera}

Penderita yang mengalami penyakit kolera harus segera mandapatkan penaganan segera, yaitu dengan memberikan pengganti cairan tubuh yang hilang sebagai langkah awal. Pemberian cairan dengan cara Infus/Drip adalah yang paling tepat bagi penderita yang banyak kehilangan cairan baik melalui diare atau muntah. Selanjutnya adalah pengobatan terhadap infeksi yang terjadi, yaitu dengan pemberian antibiotik/antimikrobial seperti Tetrasiklin, Doxycycline atau golongan Vibramicyn. Pengobatan antibiotik ini dalam waktu 48 jam dapat menghentikan diare yang terjadi.

Pada kondisi tertentu, terutama diwilayah yang terserang wabah penyakit kolera pemberian makanan/cairan dilakukan dengan jalan memasukkan selang dari hidung ke lambung (sonde). Sebanyak 50\% kasus kolera yang tergolang berat tidak dapat diatasi (meninggal dunia), sedangkan sejumlah $1 \%$ penderita kolera yang mendapat penanganan kurang adekuat meninggal dunia. ${ }^{7}$

\section{Pencegahan Penyakit kolera}

Cara pencegahan dan memutuskan tali penularan penyakit kolera adalah dengan prinsip sanitasi lingkungan, terutama kebersihan air dan pembuangan kotoran (feaces) pada tempatnya yang memenuhi standar lingkungan. Lainnya ialah meminum air yang sudah dimasak terlebih dahulu, cuci tangan dengan bersih sebelum makan memakai sabun/antiseptik, cuci sayuran dangan air bersih terutama sayuran yang dimakan mentah (lalapan), hindari memakan ikan dan kerang yang dimasak setengah matang.

Bila dalam anggota keluarga ada yang terkena kolera, sebaiknya diisolasi dan secepatnya mendapatkan pengobatan. Benda yang tercemar muntahan atau tinja penderita harus di sterilisasi, searangga lalat (vektor) penular lainnya segera diberantas. Pemberian vaksinasi kolera dapat melindungi orang yang kontak langsung dengan penderita.

Namun belajara dari Negara Bangladesh, eradikasi dengan cara pemberian vaksin, terbukti tidak efektif bagi negara-negara berkembang yang keadaan sosial-ekonominya menyedihkan. 


\section{TIMEWorld}

SEARCH TIMECOM

\begin{tabular}{l|l|l|l|l|l|l|l|l|l|l|l|l|l|l} 
Main & Global Spin & Middle East & Travel & Intelligent Cities & Videos
\end{tabular}

In Bangladesh, A New Way to Fight Cholera
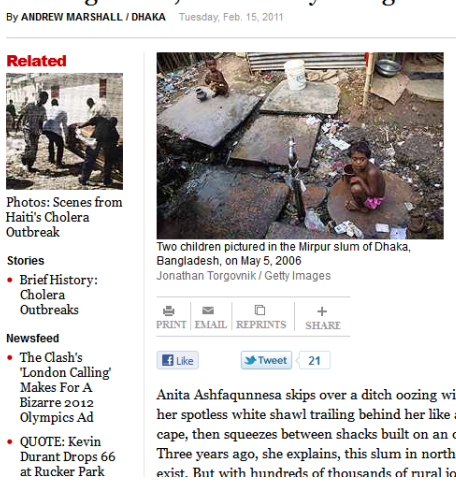

Aita Ashfaqunnesa skips over a ditch oozing with raw sewage, , thess white shawl trailing behind her like a superhero's cape, then squeezes between shacks built on an old rubbish dump. exict. Rurt with hundrads of ther slum in northern Dhaka didnt

Gambar 4. Majalah Time World. ${ }^{8}$

Diungkapkan dalam majalah dunia Time World, "A New Way to Fight Cholera", cara terbaru untuk membasmi kolera adalah dengan menjaga kebersihan diri, lingkungan, serta masyarakat.

Hal ini diungkapkan pula oleh WHO, dan langkah-langkah jitu tersebut dirumuskan dalam 3SW (Sterilization, Sewage, Sources, and Water purification).

A. Sterilisasi: Membuang dengan benar sisa defek fecal dan air yang dihasilkan oleh pasien yang menderita kolera.

B. Sewage: Pemberian antimikroba (klorin, ozon) di saluran-saluran pembuangan air guna mencegah penularan kolera.

C. Sources: Peringatan mengenai kemungkinan adanya kontaminasi di dekat sumber air yang rentan serta langkah langkah mendekontaminasinya.

D. Water purification: Semua air yang digunakan untuk minum, mencuci, dan memasak, harus disterilisasi dengan cara merebus, memberi klorin, ataupun pemberian ozon.

\section{Simpulan}

Kolera memang sudah menjadi momok yang menakutkan di dunia, dan belajar dari negara-negara di Asia yang sudah pernah mengalami wabah kolera, dapat diambil kesimpulan bahwa pengobatan dengan vaksin tidak memiliki pengaruh yang signifikan.

Selain karena tidak menjangkau seluruh warga miskin di sebuah negara, harga vaksin kolera juga dirasa cukup memberatkan anggaran negara-negara yang sedang berkembang di Asia.

Cara yang dirasa paling tepat dalam menekan laju penyebara kolera adalah 3SW (Sterilization, Sewage, Sources, and Water purification), hal ini mengingatkan kita untuk menjaga keseimbangan Agent, Host, dan Environment.

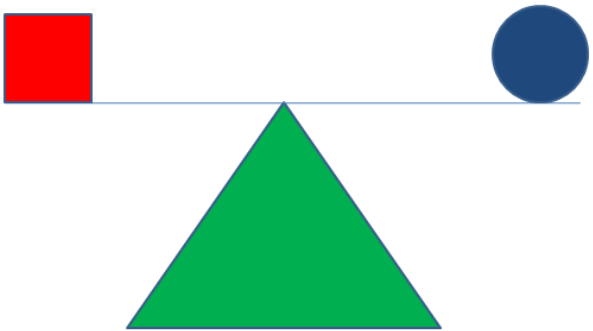

Agent (Penyebab Penyakit)

Host (Keadaan Kekebalan Tubuh)

Environment (keadaan Lingkungan Tempat Tinggal)

Gambar 5. Keseimbangan Agent Host dan Environment. ${ }^{9}$

Gangguan pada environment (lingkungan), alam di sekitar kita, akhirnya menyebabkan ketidakseimbangan di sebuah daerah dan akhirnya membawa bencana di wilayah tersebut.

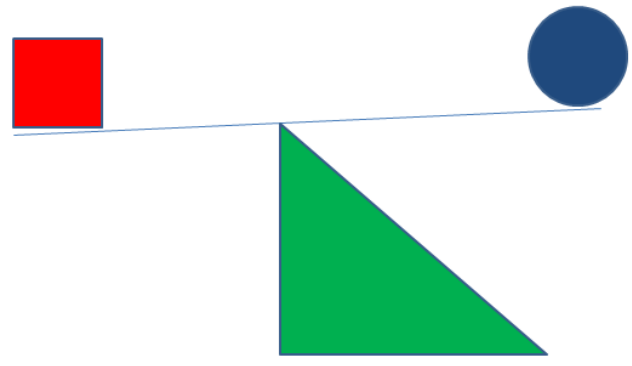

Agent (Penyebab Penyakit)

Host (Keadaan Kekebalan Tubuh)

Environment (keadaan Lingkungan Tempat Tinggal)

Gambar 6. Ketidakseimbangan Agent Host dan Environment. ${ }^{9}$

\section{Daftar Pustaka}

1. King AA, lonides EL, J.Luckhurst, Bouma MJ (August). "Inapparent infections and cholera dynamics". Nature454 (7206): 877-80. doi: $10.1038 /$ nature07084. 2008

2. Merrell DS, Butler SM, Qadri F, et al. (June). "Hostinduced epidemic spread of the cholera 
bacterium". Nature417 (6889): 642-5. doi: $10.1038 /$ nature00778.2002.

3. Holt JG, Krieg NR. Bergey's manual of determinative microbiology, 9th ed.. Baltimore: The Williams \& Wilkins Co. Hal:190-274.1994.

4. Thompson FL, lida T, Swings J.. Biodiversity of vibrios. Microbiol Mol Biol Rev 68: 403-31.2004.

5. Sack DA, Sack RB, Nair GB, Siddique AK (January). "Cholera". Lancet363 (9404): 223-33.2004.

6. Mahalanabis, dkk. An epidemic of cholera due to Vibrio cholerae 0139 in Dhaka, Bangladesh: clinical and epidemiological features. Cambridge: Cambridge University. 1994.

7. Anonim. Massachusetts medical society, : Getting Serious about Cholera. 2007

8. Andrew Marshal. In Bangladesh, A New Way to Fight Cholera. 2011

http://www.time.com/time/world/article/0,8599, 2048937,00.html

9. Amertha. Beban Global Kolera. Manado: Universitas Sam Ratulangi. 2011.

http://lebihgelapdarihitam.wordpress.com/

10. Anonim. http://en.wikipedia.org/wiki/Cholera

11. Anonim. Majalah Kesehatan Masyarakat Indonesia No 16 /XX / 2009. 